\title{
PTK7 overexpression in colorectal tumors: Clinicopathological correlation and prognosis relevance
}

\author{
XIUYUN TIAN $^{1 *}$, LIANG YAN $^{1 *}$, DONGHAI ZHANG ${ }^{2}$, XIAOYA GUAN $^{1}$, \\ $\mathrm{BIN} \mathrm{DONG}^{3}$, MIN ZHAO ${ }^{4}$ and CHUNYI HAO ${ }^{1}$ \\ ${ }^{1}$ Key Laboratory of Carcinogenesis and Translational Research, Ministry of Education/Beijing, \\ Department of Hepato-Pancreato-Biliary Surgery, Peking University Cancer Hospital and Institute; \\ ${ }^{2}$ Department of Gastroenterology, Daxing Hospital Affiliated to Capital University of Medical Sciences; \\ ${ }^{3}$ Key Laboratory of Carcinogenesis and Translational Research, Ministry of Education/Beijing, Central Laboratory, \\ Peking University Cancer Hospital and Institute; ${ }^{4}$ Key Laboratory of Carcinogenesis and Translational Research, \\ Ministry of Education/Beijing, Department of Pathology, Peking University Cancer Hospital and Institute, Beijing, P.R. China
}

Received March 9, 2016; Accepted July 18, 2016

DOI: 10.3892/or.2016.4983

\begin{abstract}
Colorectal cancer (CRC) has one of the highest mortality rates in the worldwide and its incidence has been increasing in recent years. Protein tyrosine kinase-7 (PTK7) is an inactive member of receptor protein tyrosine kinase (RPTK)-like molecules, which is involved in tumorigenesis of a variety of cancers. Our study aimed to investigate expression of PTK7 in colorectal tumors (including benign adenomas and malignant carcinomas), and its potential function in tumorigenesis and prognosis. A total of 209 CRC patients and 28 colonic adenoma patients were included in this study. Reverse transcription polymerase chain reaction (RT-PCR) and quantitative real-time PCR were performed in 14 pairs of fresh frozen tissues to evaluate mRNA expression of PTK7. Expression of PTK7 protein in 209 CRC tissues with paired non-cancerous mucosa and 28 adenoma specimens were tested using immunohistochemistry. The expression difference and its correlation with clinicopathological features and overall survival were assessed by SPSS statistics (version 22). $\mathrm{P}<0.05$ was considered significant. RT-PCR and quantitative real-time PCR showed a higher expression of PTK7 mRNA
\end{abstract}

Correspondence to: Professor Chunyi Hao, Key Laboratory of Carcinogenesis and Translational Research, Ministry of Education/Beijing, Department of Hepato-Pancreato-Biliary Surgery, Peking University Cancer Hospital and Institute, 52 Fucheng Road, Haidian, Beijing, P.R. China

E-mail: haochunyi@bjmu.edu.cn

*Contributed equally

Abbreviations: PTK7, protein tyrosine kinase-7; CRC, colorectal cancer; TMA, tissue microarray; IRS, immunoreactivity score

Key words: protein tyrosine kinase-7, colorectal cancer, colonic adenoma, immunohistochemistry, prognosis in CRC compared with non-tumorous mucosa $(4.87 \pm 3.71$ vs. $1.33 \pm 1.05 ; \mathrm{P}<0.001)$. PTK7 expression was significantly higher in adenoma (75\%) and CRC (68.3\%) than in nontumorous mucosa $(\mathrm{P}<0.001)$. PTK7 expression was correlated with tumor differentiation $(\mathrm{P}=0.027)$, lymph node metastasis $(\mathrm{P}=0.005)$, distant metastasis $(\mathrm{P}=0.001)$ and $\mathrm{TNM}$ stage $(\mathrm{P}=0.028)$ of $\mathrm{CRC}$ patients. Significant correlation between PTK7 overexpression and favorable overall survival of CRC patients was observed $(\mathrm{P}=0.005)$. Therefore, it may act as a candidate biomarker to predict the occurrence and prognosis of colorectal tumor.

\section{Introduction}

Colorectal cancer $(\mathrm{CRC})$ ranks the 4th in the mortality rates worldwide, and in China its incidence has been increasing in recent years (1). According to the Colon Cancer NCCN Guidelines (version 3.2014), metastases occur in 50-60\% CRC patients, and $80-90 \%$ of these metastatic patients may have unresectable liver metastasis (2). About $20 \%$ of CRC patients may have synchronous liver metastases (3), which probably means worse prognosis than the patients with metachronous liver metastases (4). Thus, it is crucial to explore the metastatic predictors and to clarify the mechanism underlying liver metastasis.

Protein tyrosine kinase-7 (PTK7), which is also called Colon carcinoma kinase-4 (CCK4), is one of the receptor protein tyrosine kinase (RPTK)-like molecules. A fragment of PTK7 was first cloned from normal melanocytes in 1993 (5). It is a transmembrane protein which showed general homology with many tyrosine kinases but may lack catalytical activity (6). PTK7 is one of the co-receptors for the non-canonical WNT/PCP signaling pathway, and it is involved in vertebrate embryogenesis (7). Aberrant expression of PTK7 has been found in melanoma, renal clear carcinoma, gastric cancer, epithelial ovarian carcinoma, and intrahepatic cholangiocarcinoma. Several studies have suggested that PTK7 may be implicated in carcinogenesis (8-12). However, 
whether the expression of PTK7 correlates with development and progression of $\mathrm{CRC}$ remains unclear.

Our study aimed to investigate the distinct expression of PTK7 among non-tumorous colorectal mucosa, colonic adenoma and colorectal carcinoma, and to clarify the correlation between PTK7 expression and clinicopathological features or prognosis of CRC patients, which helps to elucidate the mechanism of CRC progression and provides a potential therapeutic target.

\section{Materials and methods}

Patients and samples. Two hundred and nine patients with CRC were included in this study. They underwent surgical resection during 2004-2008 at Peking University Cancer Hospital, Beijing, China.Each tumor specimen and paired non-cancerous mucosa were formalin-fixed within $30 \mathrm{~min}$ after resection, and then embedded with paraffin. Of the 209 patients, 203 have complete clinical records. Patients who received neoadjuvant chemotherapy or radiation were excluded. All the patients were followed up for at least 5 years after surgery, wherein 12 were lost to follow-up. The clinicopathological features of the 209 CRC patients are described in Table I. Another 14 pairs of CRC tissue and paired non-cancerous mucosa were used for reverse transcription polymerase chain reaction (RT-PCR) and quantitative real-time PCR evaluation. These specimens were immediately frozen in liquid nitrogen after resection, and were stored at $-80^{\circ} \mathrm{C}$ until use. Samples of colonic adenoma of 28 patients were provided by Daxing Hospital Affiliated to Capital University of Medical Sciences (the data of clinicopathological features of the 28 patients are not shown). Informed consent was obtained from each patient. The research Ethics Committee of Peking University Cancer Hospital and that of Daxing Hospital approved this study.

RNA extraction and RT-PCR. Total RNA was extracted from 14 pairs of fresh frozen tissues using TRIzol reagent (Invitrogen Life Technologies, Carlsbad, CA, USA) following the manufacturer's instructions. Then the RNA concentration was determined by NanoDrop 2000 (Thermo Fisher Scientific, Waltham, MA, USA). Reverse transcription was performed using the 5X All-In-One RT MasterMix (ABM, Inc., Richmond, BC, Canada). In brief, $1 \mu \mathrm{g}$ of total RNA was added into a $20-\mu 1$ reaction volume, and then the mixture were incubated at $25^{\circ} \mathrm{C}$ for $10 \mathrm{~min}$, followed by synthesis at $42^{\circ} \mathrm{C}$ for $50 \mathrm{~min}$, and termination reaction at $85^{\circ} \mathrm{C}$ for $5 \mathrm{~min}$. Next, $2 \mathrm{X}$ Easy Taq PCR SuperMix (Transgen Biotech, Beijing, China) was used to build up a 30- $\mu$ l reaction volume to carry out polymerase chain reaction (PCR). The reaction conditions were as follows: pre-denaturation at $94^{\circ} \mathrm{C}$ for $5 \mathrm{~min}$; 40 cycles of denaturation at $94^{\circ} \mathrm{C}$ for $30 \mathrm{sec}$, annealing $30 \mathrm{sec}$ at $60^{\circ} \mathrm{C}$, and extension at $72^{\circ} \mathrm{C}$ for $30 \mathrm{sec}$; and the last extension at $72^{\circ} \mathrm{C}$ for $10 \mathrm{~min}$. The primer sequences were as follows: PTK7 forward, 5'-CAGTTCCTGAGGATTTCCAAGAG-3' and reverse, 5'-TGCATAGGGCCACCTTC-3'; $\beta$-actin forward, 5'-TTAGTTGCGTTACACCCTTTC-3' and reverse, 5'-ACCT TCACCGTTCCAGTTT-3'. PCR products were then separated by electrophoresis of $2 \%$ agarose gel at $80 \mathrm{~V}$ for $40 \mathrm{~min}$ and evaluated by UVP EC3 imaging system (UVP Inc., Upland, CA, USA).
Table I. Clinicopathological features of the 209 colorectal cancer patients.

\begin{tabular}{|c|c|c|}
\hline $\begin{array}{l}\text { Clinicopathological } \\
\text { features }\end{array}$ & No. of patients & $\%$ of patients \\
\hline \multicolumn{3}{|l|}{ Gender } \\
\hline Male & 128 & 61.2 \\
\hline Female & 81 & 38.8 \\
\hline \multicolumn{3}{|l|}{ Age (years) } \\
\hline$<60$ & 94 & 45.0 \\
\hline$\geq 60$ & 115 & 55.0 \\
\hline \multicolumn{3}{|l|}{ Tumor size (cm) } \\
\hline$<5$ & 113 & 54.3 \\
\hline$\geq 5-<8$ & 73 & 35.1 \\
\hline$\geq 8$ & 22 & 10.6 \\
\hline \multicolumn{3}{|l|}{ Tumor site } \\
\hline Right-side colon & 54 & 25.8 \\
\hline Transverse colon & 15 & 7.2 \\
\hline Left-side colon & 61 & 29.2 \\
\hline Rectum & 79 & 37.8 \\
\hline \multicolumn{3}{|l|}{ Differentiation } \\
\hline Well & 20 & 9.6 \\
\hline Moderate & 153 & 73.2 \\
\hline Poor & 36 & 17.2 \\
\hline \multicolumn{3}{|l|}{ Depth of invasion } \\
\hline $\mathrm{T} 1+\mathrm{T} 2$ & 30 & 14.4 \\
\hline $\mathrm{T} 3+\mathrm{T} 4$ & 179 & 85.6 \\
\hline \multicolumn{3}{|c|}{ Lymph node metastasis } \\
\hline N0 & 89 & 42.6 \\
\hline N1-2 & 120 & 57.4 \\
\hline \multicolumn{3}{|l|}{ Distant metastasis } \\
\hline M0 & 102 & 50.0 \\
\hline M1 & 102 & 50.0 \\
\hline \multicolumn{3}{|l|}{ TNM stage } \\
\hline $\mathrm{I}+\mathrm{II}$ & 69 & 33.8 \\
\hline III+IV & 135 & 66.2 \\
\hline \multicolumn{3}{|l|}{ Vascular invasion } \\
\hline Absent & 147 & 70.3 \\
\hline Present & 62 & 29.7 \\
\hline
\end{tabular}

Quantitative real-time PCR. The cDNA obtained by reverse transcription was 5-fold and 50-fold diluted for amplification of PTK7 and expressed Alu repeats (EAR) (13), respectively. The sequence of EAR primer was as follows: EAR forward, 5'-GAGGCTGAGGCAGGAGAATCG-3' and reverse, 5'-GTCGCCCAGGCTGGAGTG-3'. All reactions were performed in a $10 \mu \mathrm{l}$ total volume containing $5 \mu \mathrm{l}$ EvaGreen 2X qPCR MasterMix (ABM, Inc.), $1 \mu 1$ diluted cDNA and $0.1 \mu \mathrm{l}$ mixture of $10 \mu \mathrm{M}$ forward primer and $10 \mu \mathrm{M}$ reverse primer. The amplification condition was set up as follows: pre-denaturation at $95{ }^{\circ} \mathrm{C}$ for $10 \mathrm{~min}$, followed by 45 cycles of $15 \mathrm{sec}$ at $95^{\circ} \mathrm{C}$ and $1 \mathrm{~min}$ at $60^{\circ} \mathrm{C}$. Melt curve stage was then performed to confirm a single product formation. Each sample 
was performed in triplicate. The mRNA expression level was assessed by calculating the $2^{-\Delta \Delta \mathrm{Ct}}$ according to following steps: $\Delta \mathrm{Ct}$ were determined as the cycle threshold $(\mathrm{Ct})$ difference between PTK7 gene and reference gene EAR; then $\Delta \Delta \mathrm{Ct}$ was calculated as the difference between each individual sample and the average $\Delta \mathrm{Ct}$ value of non-tumor mucosa group, and $2^{-\Delta \Delta \mathrm{Ct}}$ was calculated thereafter.

CRC tissue microarray (TMA) construction. All specimens were H\&E stained and observed under a microscope, representative cancerous tissue and paired non-cancerous mucosae were matched to construct CRC TMA according to the methods previously described (14).

Immunohistochemistry assay. The 4- $\mu \mathrm{m}$ thick slices were baked at $72^{\circ} \mathrm{C}$ for $1 \mathrm{~h}$, and then dewaxed and rehydrated through xylene and alcohol with graded concentrations. Hydrogen peroxide $(3 \%)$ was used to eliminate activity of endogenous peroxidase for $15 \mathrm{~min}$. After PBS washing 3 times, the antigen retrieval was performed in a pressure cooker with EDTA (pH 8.0) (Beijing Zhongshan Golden Bridge Biotechnology Co., Ltd., Beijing, China). After cooling to room temperature, the sections were blocked with $5 \%$ skimmed milk at room temperature for $1 \mathrm{~h}$, followed by incubation with primary rabbit polyclonal anti-PTK7 antibody (1:7,500, SAB3500340; Sigma-Aldrich, St. Louis, MO, USA) at $4^{\circ} \mathrm{C}$ overnight. The ready-to-use EnVision ${ }^{\mathrm{TM}}$ reagent $\left(\mathrm{EnVision}^{\mathrm{TM}}\right.$ detection system $^{\mathrm{T}}$ peroxidase/DAB, rabbit/mouse; Dako, Glostrup, Denmark) was then used to bind the primary antibody. The 3,3'-diaminobenzidine tetrahydrochloride kit (Beijing Zhongshan Golden Bridge Biotechnology Co., Ltd. was used to develop substrates. After being counterstained with hematoxylin, the sections were dehydrated with graded alcohol and xylene.

Evaluation of staining. The staining of PTK7 was examined and scored under a microscope by two independent pathologists who were blinded to the patient clinical data. Immunoreactivity score (IRS) was used to assess the staining of PTK7. The percentage of positive cells (PP) was scored as 0 (negative), $1(<25 \%), 2(25-75 \%)$, and $3(>75 \%)$ respectively while the staining intensity (SI) was scored as 0 (negative), 1 (weak), 2 (moderate), and 3 (strong). IRS was determined as PP multiplied by SI, IRS=0 was determined to be 'negative' while IRS $>0$ was 'positive'.

Statistical analysis. SPSS statistics (version 22) was used to perform the statistical analysis. Independent t-test was used to compare the mRNA expression level of PTK7 between cancer tissue and non-tumorous mucosa, and two-tailed $\chi^{2}$ test was used to compare the expression of PTK7 protein in CRC TMA or adenoma. Two-tailed $\chi^{2}$ test or Fisher's exact test were performed to assess the correlation between PTK7 expression and the clinicopathological parameters. Overall survival rates were analyzed by Kaplan-Meier survival tests, and P-value was calculated via log-rank test to evaluate the correlation of the patient prognosis with PTK7 expression or other parameters. Multivariate survival analysis was performed with Cox proportional hazards regression model to identify the independent parameters affecting overall survival. $\mathrm{P}<0.05$ was considered significant.

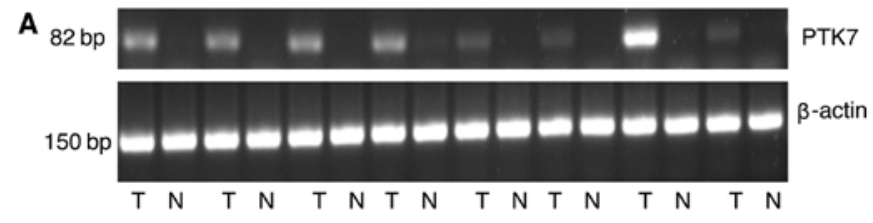

B

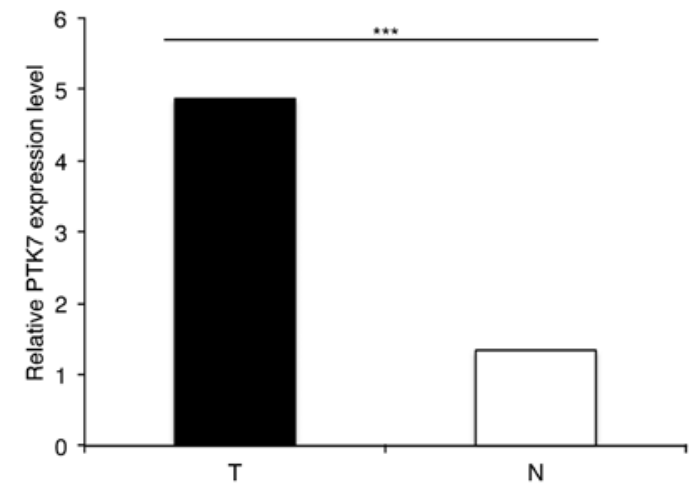

Figure 1. Protein tyrosine kinase-7 (PTK7) mRNA expression in colorectal cancer (CRC) tissues and matched non-cancerous mucosa. (A) In 12/14 pairs of tissues, PTK7 mRNA expression was higher in CRC tissues than in matched non-cancerous mucosa. (B) According to $2^{-\Delta \Delta C t}$ value, independent t-test was performed. The results further proved PTK7 mRNA expressed in high level in CRC tissues $(4.87 \pm 3.71)$, while in low level in matched non-cancerous mucosa $(1.33 \pm 1.05)$. ' $\mathrm{T}$ ' indicates 'colorectal tumour tissues', ' $\mathrm{N}$ ' indicates 'normal mucosa'; ***indicates a significant difference $(\mathrm{P}<0.001)$.

\section{Results}

PTK7 mRNA expression in 14 paired fresh frozen CRC tissues. We examined PTK7 mRNA expression in 14 pairs of CRC tissue and matched non-cancerous mucosa using RT-PCR and quantitative real-time PCR. Of the 14 pairs, 12 pairs showed that PTK7 expression was higher in tumor tissue than in non-cancerous mucosa (Fig. 1), while the remaining two pairs showed the opposite outcome. Independent t-test based on $2^{-\Delta \Delta \mathrm{Ct}}$ further indicated that PTK7 mRNA expression was significantly higher in CRC tissues than in matched noncancerous mucosa $(4.87 \pm 3.71$ vs. $1.33 \pm 1.05 ; \mathrm{P}<0.001)$.

Expression of PTK7 in colonic adenoma and its association with clinicopathological features of adenoma patients. We assessed PTK7 expression in sections of 28 patients with colonic adenoma, wherein normal colorectal mucosa was taken along with the adenoma tissue for 27 patients. PTK7 was positive in $29.6 \%$ normal mucosa and $75.0 \%$ adenoma tissues. PTK7 expression was markedly higher in colonic adenoma than in normal mucosa (75.0 vs. $29.6 \%$; $\mathrm{P}=0.001)$. Immunohistochemistry showed a cytoplasmic staining of representative expression of PTK7 (Fig. 2A).

Next, we assessed the correlation between PTK7 expression and the clinicopathological features of the adenoma patients, and in these 28 patients, we did not find a correlation between PTK7 expression and gender $(\mathrm{P}=0.198)$, age $(\mathrm{P}=0.198)$, site $(\mathrm{P}=0.065)$ or stage $(\mathrm{P}=0.841)$ of adenoma patients (data not shown).

Expression of PTK7 in CRC and its correlation with clinicopathological features of CRC patients. Of the 209 cases in the immunohistochemistry assay, 7 tumor tissues and 8 non- 
A

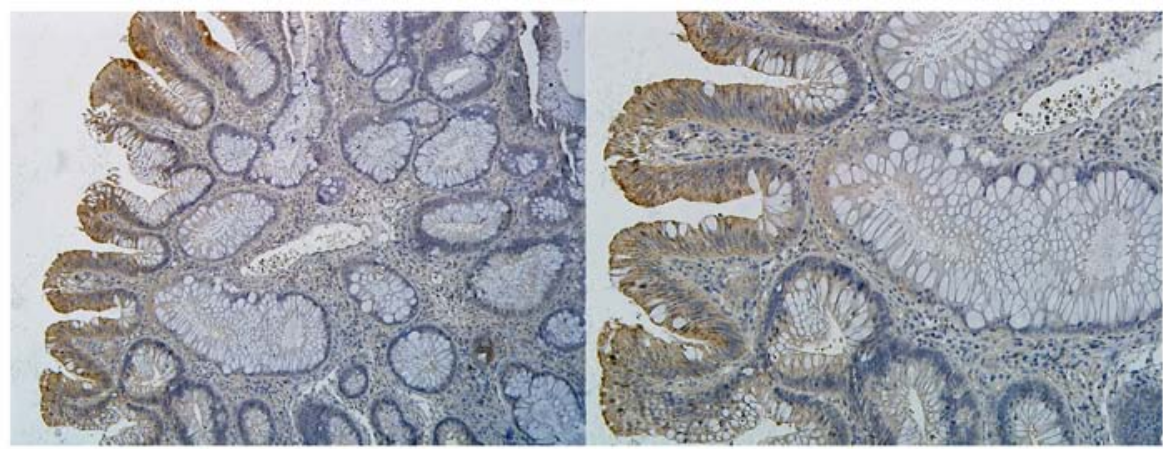

B

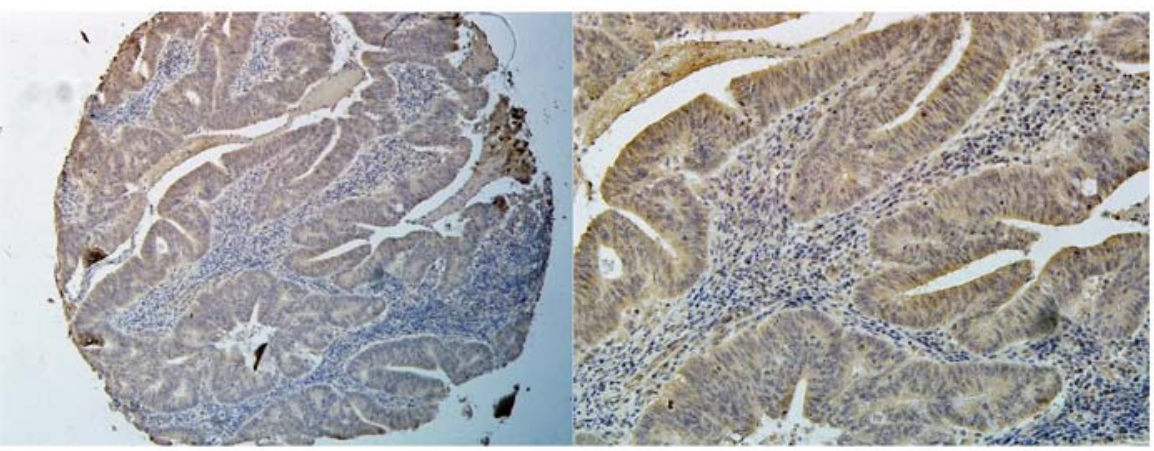

C

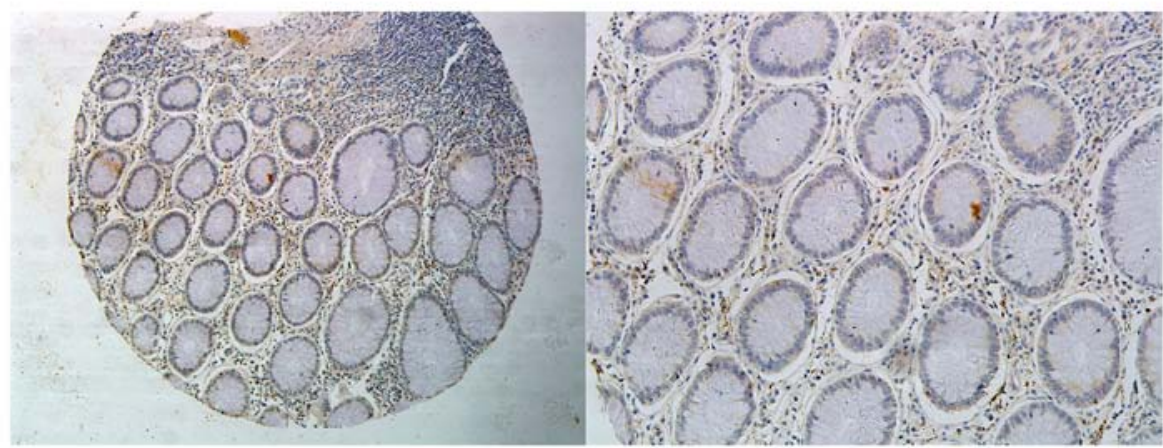

Figure 2. Typical immunohistochemical staining of protein tyrosine kinase-7 (PTK7) in (A) benign adenoma (B) colorectal cancer tissue and (C) non-cancerous mucosa (magnification: left, x100; right, x200). A typical cytoplasmic staining of PTK7 is shown in the pictures.
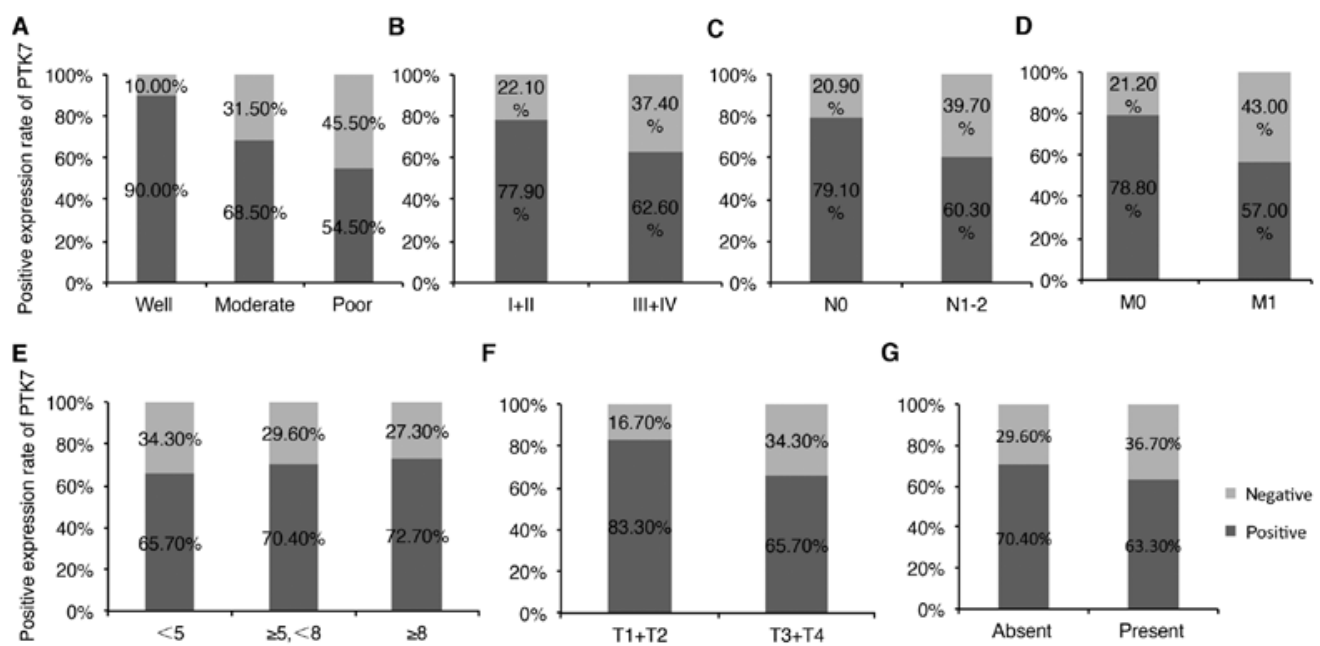

$\mathrm{F}$

G
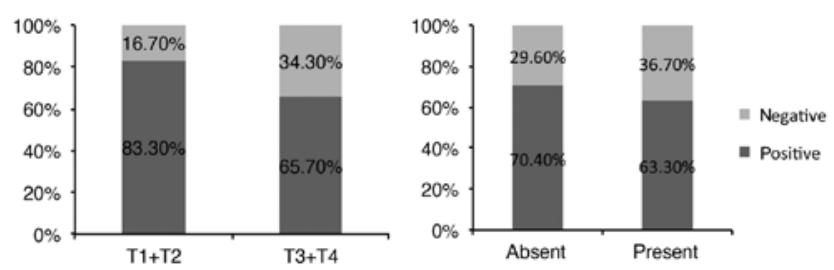

Figure 3. Positive expression rate of protein tyrosine kinase-7 (PTK7) in tumor samples with diverse clinicopathological features. (A) PTK7 was expressed significantly higher $(\mathrm{P}=0.027)$ in well-differentiated tumors $(90 \%)$, while the expression rate was reduced in moderately differentiated tumors $(68.5 \%)$ and poorly differentiated tumors (54.5\%). (B) Early-stage tumors (77.9\%) had markedly higher $(\mathrm{P}=0.028)$ expression rate of PTK7 than advanced stage tumor $(62.6 \%)$. (C) PTK7 expressed distinctly higher $(\mathrm{P}=0.005)$ in patients without lymph node metastasis $(79.1 \%)$ than in patients with lymph node metastasis $(60.3 \%)$. (D) Patients without distant metastasis $(78.8 \%)$ had significantly higher $(\mathrm{P}=0.001)$ expression of PTK7 than those with distant metastasis $(57 \%)$. (E) PTK7 expression rate ascended from small-sized tumors, medium-sized tumors to large-sized tumors $(65.7,70.40$ and $72.7 \%$, respectively), though the difference was not significant. (F) Tumors that invaded within muscularis proria $(83.3 \%)$ had higher PTK7 expression than those penetrated through muscularis proria $(65.7 \%)$. (G) Patients with vascular invasion (70.4\%) had higher PTK7 expression than those without vascular invasion (63.3\%). 
Table II. Correlation between PTK7 expression and clinicopathological features of the colorectal cancer patients.

\begin{tabular}{|c|c|c|c|c|}
\hline \multirow[b]{2}{*}{$\begin{array}{l}\text { Clinicopathological } \\
\text { features }\end{array}$} & \multirow[b]{2}{*}{$\begin{array}{l}\text { No. of } \\
\text { patients }\end{array}$} & \multicolumn{2}{|c|}{ PTK7 expression } & \multirow[b]{2}{*}{$\mathrm{P}$-value } \\
\hline & & $\begin{array}{l}\text { Positive, } \\
\text { n }(\%)\end{array}$ & $\begin{array}{l}\text { Negative, } \\
\mathrm{n}(\%)\end{array}$ & \\
\hline \multicolumn{5}{|l|}{ Gender } \\
\hline Male & 125 & $91(72.8)$ & $34(27.2)$ & \multirow[t]{2}{*}{0.081} \\
\hline Female & 77 & $47(61)$ & $30(39.0)$ & \\
\hline \multicolumn{5}{|l|}{ Age (years) } \\
\hline$<60$ & 88 & $56(63.6)$ & $32(36.4)$ & \multirow[t]{2}{*}{0.209} \\
\hline$\geq 60$ & 114 & 82 (71.9) & $32(28.1)$ & \\
\hline \multicolumn{5}{|l|}{ Tumor size $(\mathrm{cm})$} \\
\hline$<5$ & 108 & $71(65.7)$ & $37(34.3)$ & \multirow[t]{3}{*}{0.715} \\
\hline$\geq 5-<8$ & 71 & $50(70.4)$ & $21(29.6)$ & \\
\hline$\geq 8$ & 22 & $16(72.7)$ & $6(27.3)$ & \\
\hline \multicolumn{5}{|l|}{ Tumor site } \\
\hline Right-side colon & 52 & $39(75.0)$ & $13(25.0)$ & \multirow[t]{4}{*}{0.535} \\
\hline Transverse colon & 15 & $11(73.3)$ & $4(26.7)$ & \\
\hline Left-side colon & 59 & $37(62.7)$ & $22(37.3)$ & \\
\hline Rectum & 76 & $51(67.1)$ & $25(32.9)$ & \\
\hline \multicolumn{5}{|l|}{ Differentiation } \\
\hline Well & 20 & $18(90.0)$ & $2(10.0)$ & \multirow[t]{3}{*}{0.027} \\
\hline Moderate & 149 & $102(68.5)$ & $47(31.5)$ & \\
\hline Poor & 33 & $18(54.5)$ & $15(45.5)$ & \\
\hline \multicolumn{5}{|l|}{ Depth of invasion } \\
\hline $\mathrm{T} 1+\mathrm{T} 2$ & 30 & $25(83.3)$ & $5(16.7)$ & \multirow[t]{2}{*}{0.055} \\
\hline $\mathrm{T} 3+\mathrm{T} 4$ & 172 & $113(65.7)$ & $59(34.3)$ & \\
\hline \multicolumn{5}{|l|}{$\begin{array}{l}\text { Lymph node } \\
\text { metastasis }\end{array}$} \\
\hline NO & 86 & $68(79.1)$ & $18(20.9)$ & \multirow[t]{2}{*}{0.005} \\
\hline N1-2 & 116 & $70(60.3)$ & $46(39.7)$ & \\
\hline \multicolumn{5}{|l|}{ Distant metastasis } \\
\hline M0 & 99 & $78(78.8)$ & $21(21.2)$ & \multirow[t]{2}{*}{0.001} \\
\hline M1 & 100 & $57(57.0)$ & $43(43.0)$ & \\
\hline \multicolumn{5}{|l|}{ TNM stage } \\
\hline $\mathrm{I}+\mathrm{II}$ & 68 & $53(77.9)$ & $15(22.1)$ & \multirow[t]{2}{*}{0.028} \\
\hline III+IV & 131 & $82(62.6)$ & $49(37.4)$ & \\
\hline \multicolumn{5}{|l|}{ Vascular invasion } \\
\hline Absent & 142 & $100(70.4)$ & $42(29.6)$ & \multirow[t]{2}{*}{0.322} \\
\hline Present & 60 & $38(63.3)$ & $22(36.7)$ & \\
\hline
\end{tabular}

PTK7, protein tyrosine kinase-7.

cancerous mucosa tissues were off-sectioned and cannot be assessed. In the remaining specimens, PTK7 was positive in 138 of the 202 tumor tissues and 40 of the 201 non-cancerous mucosa tissues (68.3 vs. 19.9\%; $\mathrm{P}<0.001)$, respectively. Immunohistochemical staining showed that PTK7 protein was predominantly localized in the cytoplasm (Fig. 2B and C).

Among the 209 patients, PTK7 expression in tumor samples was obviously higher in CRC patients with well
Table III. Comparison of PTK7 expression in non-tumorous mucosa, adenoma and CRC.

\begin{tabular}{lccr}
\hline Groups & Positive, n (\%) & Negative, n (\%) & Total \\
\hline Non-tumorous & $48(21.1)$ & $180(78.9)$ & 228 \\
Adenoma & $21(75)$ & $7(25)$ & 28 \\
CRC & $138(68.3)$ & $64(31.7)$ & 202 \\
\hline
\end{tabular}

PTK7, protein tyrosine kinase-7; CRC, colorectal cancer.

differentiation $(\mathrm{P}=0.027)$. For patients with well, moderate, poor differentiation, PTK7 was $90,68.5$ and $54.5 \%$ positive, respectively (Fig. 3A). Early TNM stage ( $\mathrm{P}=0.028$; I+II vs. III+IV: 77.9 vs. $62.6 \%$; Fig. $3 \mathrm{~B}$ ), and in patients without lymph node metastasis $(\mathrm{P}=0.005$; lymph node metastasis vs. no lymph node metastasis: 79.1 vs. $60.3 \%$; Fig. 3C) and distant metastasis $(\mathrm{P}=0.001$; distant metastasis vs. no distant metastasis: 78.8 vs. 57\%; Fig. 3D). PTK7 expression was not significantly correlated with gender, age, tumor size, tumor site, depth of invasion and vascular invasion of CRC patients. For detailed information, see Table II. Expression of PTK7 between tumors with diverse tumor size, depth of invasion and vascular invasion were also compared as shown in Fig. 3E-G. PTK7 expression was a little higher in tumors with larger size (from small size to large size, the positive rate were 65.7, 70.4 and $72.7 \%$, respectively; Fig. 3E), deeper tumor invasion (T1+T2 vs. T3+T4: 83.3 vs. $65.7 \%$; Fig. $3 F$ ) and occurrence of vascular invasion (vascular invasion vs. without vascular invasion: 70.4 vs. $63.3 \%$; Fig. 3G).

Comparison of PTK7 expression in non-tumorous mucosa, adenoma and $C R C$. We further compared PTK7 expression in non-tumorous mucosa, colonic adenoma and CRC (Table III). Normal colorectal mucosa taken along with adenoma and the matched non-cancerous mucosa in CRC TMA were consolidated for statistical analysis. As shown in Fig. 4, PTK7 expression was lowest in non-tumor mucosa (21.1\%) and highest in adenoma group (75.0\%). PTK7 expression in adenoma was a little higher than it in malignant tumor (75.0 vs. $68.3 \%$; $\mathrm{P}=0.515)$.

PTK7 expression was correlated with better overall survival of CRC patients. Kaplan-Meier survival analysis and log-rank test showed a significant correlation between PTK7 overexpression and longer survival time $(\mathrm{P}=0.005$, Fig. 5). The median survival time was $40.11 \pm 3.48$ months for PTK7-negative patients and 87.11 \pm 3.67 months for PTK7-positive patients, respectively.

Various clinicopathological features that may affect overall survival were evaluated by univariate survival analysis. PTK7 was confirmed to be one of the prognostic factors (HR, 0.464; 95\% CI, 0.269-0.8; $\mathrm{P}=0.006$ ). Other prognostic factors included tumor differentiation $(\mathrm{P}=0.006)$, tumor stage $(\mathrm{P}<0.001)$ and vascular invasion $(\mathrm{P}<0.001)$. These prognostic factors were included in Cox multivariate model. PTK7 was shown to be a novel independent prognostic factor of overall survival (HR, 0.453; 95\% CI, 0.254-0.809; P=0.007). Vascular 


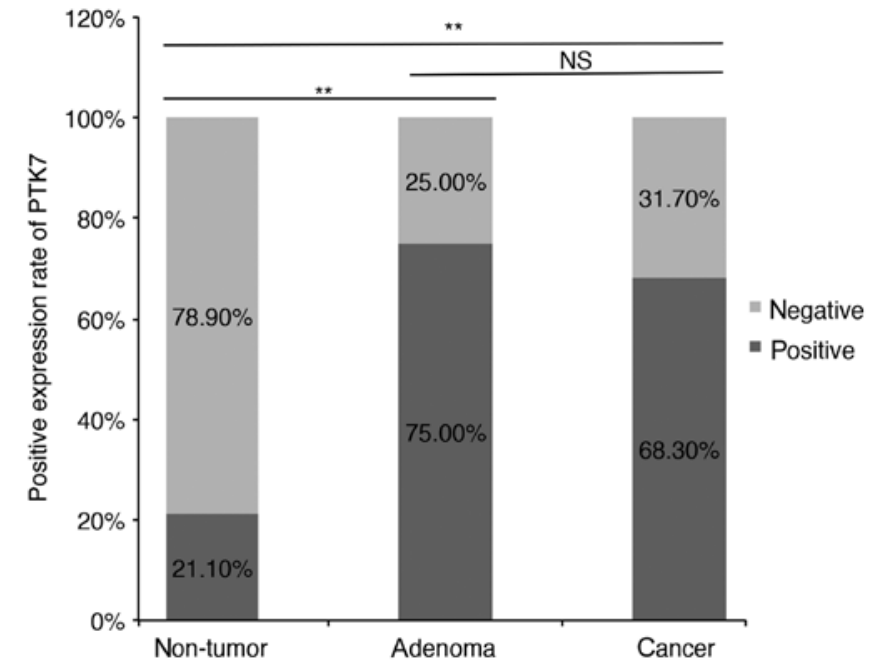

Figure 4. Protein tyrosine kinase-7 (PTK7) expression in non-tumorous mucosa $(48 / 228)$, adenoma $(21 / 28)$ and CRC tissues $(138 / 202){ }^{* *} \mathrm{P}<0.01$; NS, not significant.

invasion was also shown to be an independent prognostic factor (HR, 2.236; 95\% CI, 1.158-4.318; P=0.017). Detailed information are shown in Table IV.

\section{Discussion}

PTK7 is a member of receptor tyrosine kinases (RPTK)-like molecules. Recent studies have found that PTK7, as one of the co-receptors of non-canonical WNT signals, was involved in embryonic development (15), and it regulates convergent extension, neural tube closure as well as orientation of inner ear hair cells $(7,16)$ through WNT/PCP signaling pathway. In addition, PTK7 was found to play a role in angiogenesis (17) and epidermal wound repair (18) as well as tumorigenesis.

PTK7 was generally regarded as an oncogene. Several studies have found that PTK7 was overexpressed in erythroleukemia cell line (6), AML (19), liposarcoma (20), gastric cancer (10), esophageal squamous cell carcinoma (21), prostate cancer (22) and glioma (23). However, downregulation

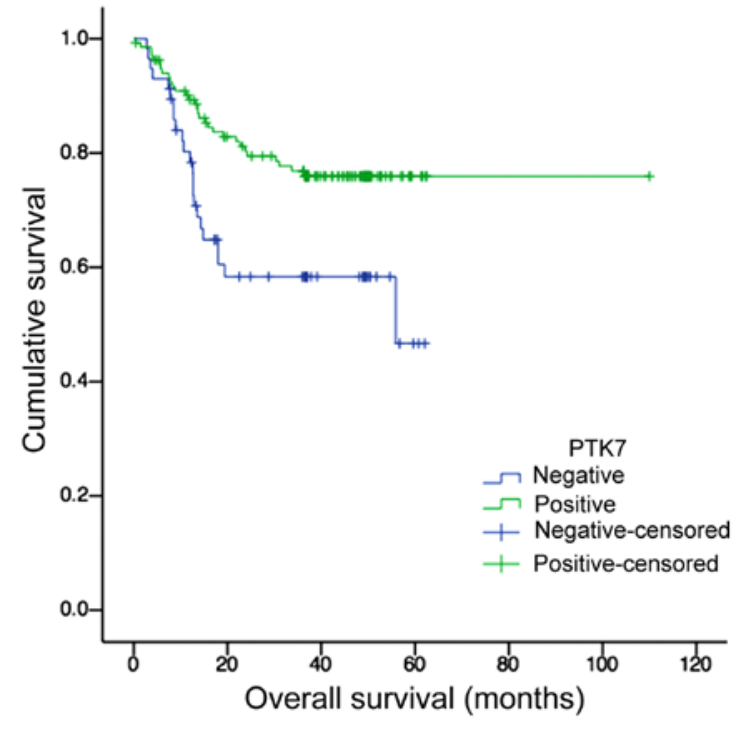

Figure 5. Kaplan-Meier survival analysis according to protein tyrosine kinase-7 (PTK7) expression in all patients showed that patients with positive expression of PTK7 had a better overall survival (87.11 \pm 3.67 months) than those with negative expression of PTK7 (40.11 \pm 3.48 months) $(\mathrm{P}=0.005)$.

of PTK7 has also been observed in several tumors including melanoma (8), clear cell renal cell carcinoma (9), lung squamous cell carcinoma (24), epithelial ovarian carcinoma (12), and hepatocellular carcinoma (25).

Our results have proved that PTK7 was overexpressed in colorectal carcinoma both in mRNA level and protein level, which is consistent with the results of Mossie et al (26) and Lhoumeau et al (27). Compared with these two studies, our study included more patients and also evaluated the expression of PTK7 in benign colonic adenoma, which has not been reported before. PTK7 was expressed in $75 \%$ adenoma, which is a little higher than in CRC tissues (68.3\%). Moreover, in CRC tissues, PTK7 expression ascended while the tumor size increased. The difference did not reach a statistically significant level $(\mathrm{P}=0.515$ and $\mathrm{P}=0.715$, respectively), but this phenomenon may be a clue that PTK7 was involved in a process of transforming normal cells into tumor cells and

Table IV. Cox proportional hazards regression model analysis.

\begin{tabular}{|c|c|c|c|c|c|c|}
\hline \multirow[t]{2}{*}{ Variables } & \multicolumn{3}{|c|}{ Univariate analysis } & \multicolumn{3}{|c|}{ Multivariate analysis } \\
\hline & Relative risk & $95 \% \mathrm{CI}$ & P-value & Relative risk & $95 \% \mathrm{CI}$ & P-value \\
\hline $\begin{array}{l}\text { Differentiation } \\
\text { (Well/moderate/poor) }\end{array}$ & 2.054 & $1.225-3.445$ & 0.006 & & & 0.660 \\
\hline $\begin{array}{l}\text { Stage } \\
(\mathrm{I}+\mathrm{II} \text { vs. III+IV) }\end{array}$ & 58.917 & $6.427-540.077$ & $<0.001$ & 403543.310 & $1.7 \times 10^{-88}-9.9 \times 10^{98}$ & 0.906 \\
\hline $\begin{array}{l}\text { Vascular invasion } \\
\text { (Present vs. absent) }\end{array}$ & 4.953 & $2.869-8.550$ & $<0.001$ & 2.236 & $1.158-4.318$ & 0.017 \\
\hline $\begin{array}{l}\text { PTK7 expression } \\
\text { (Positive vs. negative) }\end{array}$ & 0.464 & $0.269-0.800$ & 0.006 & 0.453 & $0.254-0.809$ & 0.007 \\
\hline
\end{tabular}


can promote cell growth. Overexpression of PTK7 in both colonic adenoma and carcinoma indicated that PTK7 may be an oncogene.

We also found that lower PTK7 expression was associated with poor-differentiation $(\mathrm{P}=0.036)$, lymph node metastasis $(\mathrm{P}=0.005)$, distant metastasis $(\mathrm{P}=0.001)$ and advanced TNM stage $(\mathrm{P}=0.028)$ of $\mathrm{CRC}$ patients. As shown in Fig. 3, PTK7 was $90,68.5$ and $54.5 \%$ positive in well, moderately and poorly differentiated tumors, respectively. The expression rate descended while the degree of tumor malignancy increased. Similar trend can also be seen in tumor stage, that is, PTK7 expression is relatively lower in tumors in later stage. The correlation between PTK7 expression and tumor clinicopathological features indicated a tumor suppressor gene function of PTK7, which is consistent with the study of Wang et al (12) in epithelial ovarian carcinomas.

Furthermore, our data showed that overexpression of PTK7 correlated with favorable prognosis, which is contrary to the results of Lhoumeau et al (27), but similar with that in gastric cancer (10). We classified the CRC patients according to distant metastasis or not, PTK7 was expressed in $78.8 \%$ patients of non-metastases group and $67.8 \%$ patients of metastases group $(\mathrm{P}=0.049)$. PTK7 expression showed a gradually decreasing tendency with tumor progression, which is consistent with melanoma (8) and pulmonary adenocarcinoma (28).

The reasons underlying the diverse functions of PTK7 in different tumors still remain unclear. As PTK7 has several transcriptional variants, we infer that its diverse function and distribution may be attributed to the different variants (29). Recent studies have shown different functions of full-length PTK7 and its soluble fragment generated by MT1-MMP. The enforced expression of full-length PTK7 can inhibit tumor invasion due to actin cytoskeleton reorganization (30). Thus, more specific investigation may be needed to elucidate the mechanism of PTK7 function.

In conclusion, we evaluated the expression of PTK7 protein in non-tumorous mucosa, benign colonic adenoma and malignant colorectal carcinoma, and the trend of expression rate appears rising early but declining along with the tumor progression. Expression of PTK7 correlates with lymph node metastasis and distant metastasis. CRC patients with higher PTK7 expression have better prognosis. Therefore, PTK7 may become a candidate biomarker of colorectal carcinoma metastasis.

\section{Acknowledgements}

This study was supported by the International Science and Technology Cooperation Program of China (approval no. 2013DFG32720), the Capital Health Research and Development of Special Funds (approval no.2016-2-2151), the Beijing Municipal Natural Science Foundation (approval no. 7153161), and the National Natural Science Funding (approval nos. 81441071, 61372028, 61571437 and 81272765).

\section{References}

1. Holmes D: A disease of growth. Nature 521: S2-S3, 2015.

2. NCCN Clinical Practice Guidelines in Oncology: Colon Cancer (version 3.2014). National Comprehensive Cancer Network, 2014.
3. Muratore A, Zorzi D, Bouzari H, Amisano M, Massucco P, Sperti E and Capussotti L: Asymptomatic colorectal cancer with un-resectable liver metastases: Immediate colorectal resection or up-front systemic chemotherapy? Ann Surg Oncol 14: 766-770, 2007.

4. Tsai MS, Su YH, Ho MC, Liang JT, Chen TP, Lai HS and Lee PH: Clinicopathological features and prognosis in resectable synchronous and metachronous colorectal liver metastasis. Ann Surg Oncol 14: 786-794, 2007.

5. Lee ST, Strunk KM and Spritz RA: A survey of protein tyrosine kinase mRNAs expressed in normal human melanocytes. Oncogene 8: 3403-3410, 1993.

6. Park SK, Lee HS and Lee ST: Characterization of the human full-length PTK7 cDNA encoding a receptor protein tyrosine kinase-like molecule closely related to chick KLG. J Biochem 119: 235-239, 1996

7. Katoh M: WNT/PCP signaling pathway and human cancer (Review). Oncol Rep 14: 1583-1588, 2005.

8. Easty DJ, Mitchell PJ, Patel K, Flørenes VA, Spritz RA and Bennett DC: Loss of expression of receptor tyrosine kinase family genes PTK7 and SEK in metastatic melanoma. Int J Cancer 71: 1061-1065, 1997.

9. Behbahani TE, Thierse C, Baumann C, Holl D, Bastian PJ, von Ruecker A, Müller SC, Ellinger J and Hauser S: Tyrosine kinase expression profile in clear cell renal cell carcinoma. World J Urol 30: 559-565, 2012.

10. Lin Y, Zhang LH, Wang XH, Xing XF, Cheng XJ, Dong B, Hu Y, Du H, Li YA,Zhu YB, et al: PTK7 as a novel marker for favorable gastric cancer patient survival. J Surg Oncol 106: 880-886, 2012.

11. Jin J, Ryu HS, Lee KB and Jang JJ: High expression of protein tyrosine kinase 7 significantly associates with invasiveness and poor prognosis in intrahepatic cholangiocarcinoma. PLoS One 9: e90247, 2014

12. Wang H, Li G, Yin Y, Wang J, Wang H, Wei W, Guo Q, Ma H, Shi Q, Zhou X, et al: PTK7 protein is decreased in epithelial ovarian carcinomas with poor prognosis. Int J Clin Exp Pathol 7: 7881-7889, 2014.

13. Marullo M, Zuccato C, Mariotti C, Lahiri N, Tabrizi SJ, Di Donato $\mathrm{S}$ and Cattaneo E: Expressed Alu repeats as a novel, reliable tool for normalization of real-time quantitative RT-PCR data. Genome Biol 11: R9, 2010.

14. Zhang Y, Guan XY, Dong B, Zhao M, Wu JH, Tian XY and Hao CY: Expression of MMP-9 and WAVE3 in colorectal cancer and its relationship to clinicopathological features. J Cancer Res Clin Oncol 138: 2035-2044, 2012.

15. Jung JW, Shin WS, Song J and Lee ST: Cloning and characterization of the full-length mouse Ptk7 cDNA encoding a defective receptor protein tyrosine kinase. Gene 328: 75-84, 2004.

16. Lu X, Borchers AG, Jolicoeur C, Rayburn H, Baker JC and Tessier-Lavigne M: PTK7/CCK-4 is a novel regulator of planar cell polarity in vertebrates. Nature 430: 93-98, 2004.

17. Shin WS, Maeng YS, Jung JW, Min JK, Kwon YG and Lee ST: Soluble PTK7 inhibits tube formation, migration, and invasion of endothelial cells and angiogenesis. Biochem Biophys Res Commun 371: 793-798, 2008.

18. Caddy J, Wilanowski T, Darido C, Dworkin S, Ting SB, Zhao Q, Rank G, Auden A, Srivastava S, Papenfuss TA, et al: Epidermal wound repair is regulated by the planar cell polarity signaling pathway. Dev Cell 19: 138-147, 2010.

19. Müller-Tidow C, Schwäble J, Steffen B, Tidow N, Brandt B, Becker K, Schulze-Bahr E, Halfter H, Vogt U, Metzger R, et al: High-throughput analysis of genome-wide receptor tyrosine kinase expression in human cancers identifies potential novel drug targets. Clin Cancer Res 10: 1241-1249, 2004.

20. Gobble RM, Qin LX, Brill ER, Angeles CV, Ugras S, O'Connor RB, Moraco NH, Decarolis PL, Antonescu C and Singer S: Expression profiling of liposarcoma yields a multigene predictor of patient outcome and identifies genes that contribute to liposarcomagenesis. Cancer Res 71: 2697-2705, 2011.

21. Shin WS, Kwon J, Lee HW, Kang MC, Na HW, Lee ST and Park JH: Oncogenic role of protein tyrosine kinase 7 in esophageal squamous cell carcinoma. Cancer Sci 104: 1120-1126, 2013.

22. Zhang H, Wang A, Qi S, Cheng S, Yao B and Xu Y: Protein tyrosine kinase 7 (PTK7) as a predictor of lymph node metastases and a novel prognostic biomarker in patients with prostate cancer. Int J Mol Sci 15: 11665-11677, 2014.

23. Liu Q, Zhang C, Yuan J, Fu J, Wu M, Su J, Wang X, Yuan X and Jiang W: PTK7 regulates Id1 expression in CD44-high glioma cells. Neuro-oncol 17: 505-515, 2015. 
24. Kim JH, Kwon J, Lee HW, Kang MC, Yoon HJ, Lee ST and Park JH: Protein tyrosine kinase 7 plays a tumor suppressor role by inhibiting ERK and AKT phosphorylation in lung cancer. Oncol Rep 31: 2708-2712, 2014.

25. Hishida M, Inokawa Y, Takano N, Nishikawa $\mathrm{Y}$, Iwata N, Kanda M, Tanaka C, Kobayashi D, Yamada S, Nakayama G, et al: Protein tyrosine kinase 7: A hepatocellular carcinoma-related gene detected by triple-combination array. J Surg Res 195: 444-453, 2015.

26. Mossie K, Jallal B, Alves F, Sures I, Plowman GD and Ullrich A: Colon carcinoma kinase-4 defines a new subclass of the receptor tyrosine kinase family. Oncogene 11: 2179-2184, 1995.

27. Lhoumeau AC, Martinez S, Boher JM, Monges G, Castellano R, Goubard A, Doremus M, Poizat F, Lelong B, de Chaisemartin C, et al: Overexpression of the Promigratory and Prometastatic PTK7 Receptor Is Associated with an Adverse Clinical Outcome in Colorectal Cancer. PLoS One 10: e0123768, 2015.
28. Endoh H, Tomida S, Yatabe Y, Konishi H, Osada H, Tajima K, Kuwano H, Takahashi T and Mitsudomi T: Prognostic model of pulmonary adenocarcinoma by expression profiling of eight genes as determined by quantitative real-time reverse transcriptase polymerase chain reaction. J Clin Oncol 22: 811-819, 2004.

29. Jung JW, Ji AR, Lee J, Kim UJ and Lee ST: Organization of the human PTK7 gene encoding a receptor protein tyrosine kinase-like molecule and alternative splicing of its mRNA. Biochim Biophys Acta 1579: 153-163, 2002.

30. Golubkov VS, Chekanov AV, Cieplak P, Aleshin AE, Chernov AV, Zhu W, Radichev IA, Zhang D, Dong PD and Strongin AY: The Wnt/planar cell polarity protein-tyrosine kinase-7 (PTK7) is a highly efficient proteolytic target of membrane type-1 matrix metalloproteinase: Implications in cancer and embryogenesis. J Biol Chem 285: 35740-35749, 2010. 